\title{
House of God redux
}

\author{
Return to The House of God: Medical \\ Resident Education 1978-2008 \\ Martin Kohn, Carol Donley, Editors \\ The Kent State University Press, 2008. \\ 241 pp $\$ 24.95$
}

I still recall the day I read House of God. ${ }^{1}$ It wasn't a particularly good day; I had been kicked by an attending who was frustrated by my inability to recall the external landmarks of the right middle lobe of the lung during a first-year clinical skills seminar. I was still finishing my English degree so I buried my humiliation in the stacks of the campus library and stumbled across Sam Shem's remarkable satire, widely regarded as one of the most influential novels about medical education in the 20th century. In it, Roy Basch tells the story of his year as an intern.

In the beginning Basch is enthusiastic, intelligent and thoughtful about medicine and life. Assigned to work under a senior resident dubbed "The Fat Man," Roy becomes privy to the " 13 Rules of the House of God." These

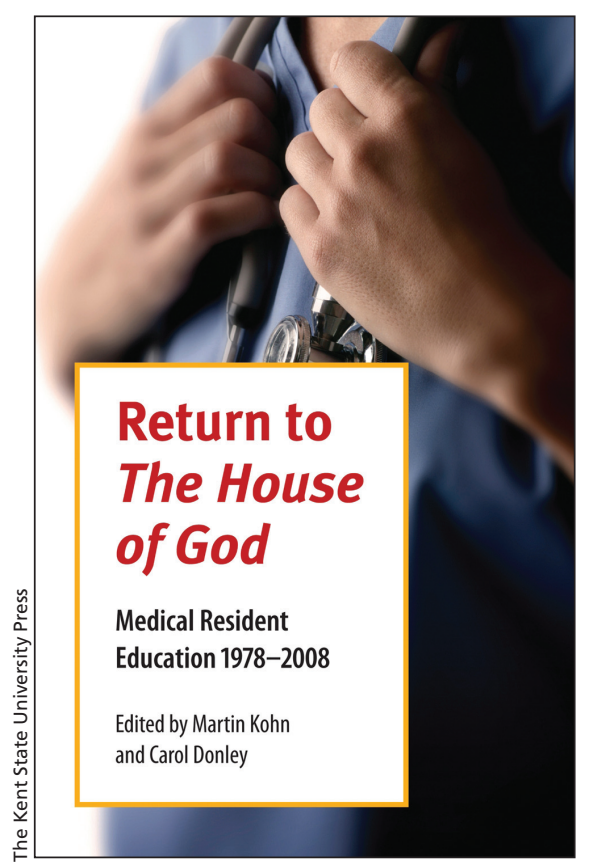

Shem's book put my experience in context. I acknowledged that while I didn't deserve what had happened, I had to prepare myself for future training experiences that were going to be far more challenging.

\section{Sam Shem strikes again, some three decades later, with more good advice.}

unconventional strategies guide the care of inpatients and earn the Fat Man's team a reputation as the best in the hospital. Despite this clinical success, Roy finds being in the presence of suffering, clinical helplessness, emotional and physical exhaustion and profound isolation alarming. His resiliency fades with his humanity, his personality shifts to reflect nihilism and cynicism, and he acts out sexually, violently and verbally. One of his colleagues, haunted by a patient's death, commits suicide. With the help of a psychiatry resident, Roy ends the year battered, broken, but in recovery. He pursues a career in psychiatry, commits to a healthy long-term relationship and uses his well-earned vacation to rediscover his humanity.
But my training (1995-2000) was incredibly different than Roy's: I enjoyed my clerkship, residency and fellowship immensely, and will forever be grateful to the many brilliant and supportive educators who touched my life during those years. Clearly, positive forces of change had affected postgraduate education since Shem's day.

Kohn and Donley have revisited the House of God and created a thoughtprovoking compilation of essays reflecting on the (d)evolution of residency training in the decades after the Fat Man's rules. They cluster the essays by themes of history, philosophy, literary criticism and analysis, and feminist perspectives. The range of authors is as impressive as it is varied, including John
Updike, Dr. Jay Baruch and Dr. Abraham Verghese. Delightfully, they leave the final word to Stephen Bergman (aka Sam Shem) and his wife Janet Surrey.

While this volume is not likely to be of interest to a wide audience of physicians, it will be of particular interest to those involved in resident education and training. The compendium is packed with postmodern perspectives, passionate voices of change and thoughtful ideas from resident and patient advocates. Unfortunately, the movers and shakers at the regulatory and academic levels, who were instrumental in overseeing this (d)evolution, remain nameless. In addition, the viewpoint reflects the challenges in the United States, a world that is not immediately familiar to me, or, in all likelihood, many international readers.

Canadian readers will, however, identify with the essay by Kenneth Ludmerer and his recommendations for graduate education: residents need to see patients in more depth, not more quantity; residents need to be relieved of noneducational work that can be done by others; educational opportunities afforded to residents must improve in quality (content, delivery, evaluation); and programs need to respond better to the emotional needs of trainees and promote their health and sustainability.

In closing, Bergman gives readers new rules of care focused not on the patient, but on the resident physician. He urges trainees to avoid isolation, speak up, resist self-centeredness, learn empathy and learn their trade in the real world. Sam Shem strikes again, some three decades later, with more good advice that reflects contemporary understandings of physician health and sustainable practice.

\section{Derek Puddester MD}

Director, Faculty Wellness Program University of Ottawa Ottawa, Ont.

\section{REFERENCE}

1. Shem S. The house of God. New York (NY): Dell; 1978. 